Research, part of a Special Feature on Twenty Years of Community Forestry in Cameroon: Opportunities and Challenges for Sustainable Development

\title{
Are community forests a viable model for the Democratic Republic of Congo?
}

\author{
Guillaume Lescuyer $^{1,2}$, Tito Muhindo Kakundika ${ }^{3,4}$, Ignace Muganguzi Lubala ${ }^{5}$, Isaac Shabani Ekyamba ${ }^{4}$, Raphaël Tsanga $^{6}$ \\ and Paolo Omar Cerutti ${ }^{7}$
}

\begin{abstract}
Since the second half of the 2000s, several options for implementing community-based forest management in the Democratic Republic of Congo (DRC), like the local community forest concession (LCFC), have been discussed in the country's technical and political circles. Proposals and pilot testing have increased in the last five years, but the funding of initiatives is often proposed for divergent purposes and taking different approaches. We reviewed current experiences in the Eastern province of the DRC and found that nobody has carried out an estimation of the financial returns of the business models they drew up for/with the communities involved. We therefore conducted a financial feasibility analysis for two case studies, estimating the costs of developing/ implementing activities and the benefits expected for the communities within the next five years. Three main conclusions were drawn from the analysis: (1) most activities conducted under the LCFC model deal with rural development, and not with forestry operations per se; (2) several forestry activities such as biodiversity conservation or carbon sequestration are not detailed in the management documents and appear to have little legitimacy for local populations; (3) the two LCFCs show a negative financial performance because the inception and implementation costs are substantially higher than the medium-term profits. Community forestry is unlikely to develop in the DRC unless local people are guaranteed that it will contribute to improving their livelihoods, notably their financial and physical capital. This requires that LCFC initiatives focus on actual productive uses of forest resources, which financial performance is systematically assessed ex ante. A simplification of the legal constraints is also needed to reduce the cost of creating and managing a LCFC.
\end{abstract}

Key Words: Cameroon; community forestry; Congo basin; cost-benefit analysis; livelihoods

\section{INTRODUCTION}

\section{No successful community forests in Central Africa without livelihood improvement}

Social forestry emerged in the 1970 s and quickly took a variety of forms, including community-based forest management (CBFM), which most directly involves local populations in forest management (Cernea 1986, Nguinguiri 1999). Evidence of successful common property regimes in various contexts combined with the failures of centralized management in controlling deforestation have led governments to increasingly consider CBFM as a solution for achieving the objectives of sustainable development: it should increase welfare for rural populations, conserve forest resources, and improve local governance through the transfer of management authority and the recognition of customary rights over lands and resources (Gibson et al. 2000, Kellert et al. 2000, Pagdee et al. 2006, Maryudi et al. 2012). In reality, the benefits of the CBFM programs have often failed to materialize. Even where central governments have actually ceded authority and management of forests to local communities, the lack of attention to institutional and social factors is usually presented as the main reason to explain that CBFM initiatives have fallen short of their stated goals (Edmunds and Wollenberg 2003, Tole 2010). There is a very rich literature on institutional arrangements for CBFM, which theorizes that the success of community forestry is governed by the prior establishment of an adequate institutional framework and the strengthening of social capital (Hanna et al. 1996, Pagdee et al. 2006, Tole 2010, Baynes et al. 2015). This assumption of the preeminence of institutional and social conditions in the success of community forestry may be questioned when the people, who will ultimately have to implement the community forestry model, live in very harsh conditions and struggle to meet their basic needs. In these conditions, the weak evidence of a significant economic impact of community forestry on local livelihoods is an overlooked obstacle to the success and the extension of this approach (Baynes et al. 2015). Hajjar et al. (2016) carried out a comprehensive review of CBFM performance and showed that livelihood outcomes were reported in $30-40 \%$ of the cases, and that only $24 \%$ were measured using quantitative surveying techniques. In addition, most of this work focused on ways of covering local needs (Padgee et al. 2006) or on the equitable distribution of benefits among community members (Thoms 2008), and not on increasing the net incomes of rural households. Few studies carried out ex ante or ex post quantification of individual and collective livelihood outcomes at village level (Tole 2010, Hajjar et al. 2016). In addition, when a financial assessment of the CBFM scheme was carried out, Humphries et al. (2012, 2018) showed that most cases did not include the full range of costs and neglected potentially large costs, such as technical assistance and machinery depreciation, which are subsidized.

In Central Africa, the focus of this article, a similar observation can be made on Cameroon, the first country to legally adopt and implement the CBFM model since the 1990s, with the aim to exploit forest resources sustainably for the benefit of the communities and, to some extent, according to their own rules (Ekoko 2000, Topa et al. 2009). Cameroon adopted this approach in 1994 and implemented it from the end of the 1990s. The creation of formal community forests (CF) allowed village associations to

${ }^{1}$ CIRAD Forêts et Sociétés, Univ Montpellier, Montpellier, France, ${ }^{2}$ CIFOR, Bogor, Indonesia, ${ }^{3}$ Université Officielle de Ruwenzori, Butembo, Democratic Republic of Congo, ${ }^{4}$ University of Kisangani, Faculty of Sciences, Kisangani, Democratic Republic of Congo, ${ }^{5}$ Océan, Kisangani, Democratic Republic of Congo, ${ }^{6} \mathrm{CIFOR}$, Yaounde, Cameroon, ${ }^{7} \mathrm{CIFOR}$, Nairobi, Kenya 
legally harvest, process, and trade forest resources over a maximum area of 5000 hectares respecting the rules of a simple management plan (SMP) approved by the administration. But the absence of significant impacts of CBFM on rural livelihoods and the complicated administrative procedures have hindered the extension of this model. In 2017, out of 335 validated SMPs, 274 of them had been completed with the signature of a letter of agreement with the public authorities. However, only 161 of them were active as they benefitted from a Certificate of Harvesting License. Twenty years after the creation of the CFs, it is only about $1 \%$ of the national area of Cameroon that is operated under $\mathrm{CF}$ status, and $2 \%$ of the national land area that is allocated to CFs (most of which are not active). This relative failure must be linked to the governance of the forest sector, which is still not very favorable to social forestry, but also and mainly to the weak impact of this approach on rural populations.

In Cameroon, the objective assigned to community forestry was primarily social and institutional (Etoungou 2003, Cuny et al. 2004, Oyono 2005, Assembe Mvondo et al. 2011). It relied on the premise that communities are closely related to the surrounding forests, not only for their daily livelihood but also for cultural and religious purposes. They were therefore expected to play an important role in the common decision-making procedures and implementation of forestry activities. But in poor rural societies, such as in the forest zone of Cameroon, people's engagement in community forestry is motivated by their expectations of raising their standard of living (De Jong et al. 2018). According to the sustainable livelihoods framework (Chambers and Conway 1992, Scoones 1998), rural livelihoods are made of five types of assets, two of which focus on the material conditions of the communities: (1) physical capital, i.e., the capital base that is essential for the pursuit of any livelihood strategy; (2) financial capital, i.e., income, savings, credit, and other inflows. However, the rise of these two types of capital has been disappointing for 20 years in Cameroon, for three reasons.

First, the start-up costs for a community forest are out of the reach of local populations: it is necessary to spend more than US\$30,000 even before signing the CF management agreement with the administration (Lescuyer et al. 2016). Such a level of starting costs is partly because of the complex and expensive regulations imposed on creating and running a $\mathrm{CF}$ in Cameroon (Vermeulen et al. 2006, Julve Larrubia et al. 2013). It explains the dependence of communities on external actors who can financially and technically support the upfront costs of $\mathrm{CF}$ creation and utilization. For example, it is extremely rare for a community to engage in a community forestry process without the support, or even leadership, of an NGO or an elite. Forest companies also provide important technical support to communities because most CFs are exploited through a subcontract with a logging company, not by the communities themselves (Vermeulen et al. 2006, Cuny 2011, Julve Larrubia et al. 2013). Thus these external actors capture part of the subsidies or rent derived from the exploitation of forest resources, which were a priori intended for local populations.

Second, the low (and sometimes negative) level of profit has been a common criticism of community forestry in Cameroon. Logging is the main source of revenues from CFs but this activity remains marginal, with a global turnover in Cameroon of around
US\$2 million per year (Lescuyer et al. 2016). Local people remain the primary beneficiaries of community forestry, mainly because of income that is generated from logging and distributed to workers (Nzoyem, Vabi, Kouokam, and Azanga 2010, unpublished manuscript). These individual incomes are very low when equally distributed among the community members (Cuny 2011, Oyono et al. 2012) and without considering the usually poor distribution of $\mathrm{CF}$ revenues in favor of local political, economic, or military elites (Oyono 2005, Ribot et al. 2010). Last, few collective investments were funded by the revenues drawn from the exploitation of the CFs because of the low level of net profit and of institutional problems within the CF management committee (Oyono et al. 2006, 2012, Ezzine de Blas et al. 2009, Cuny 2011).

The low impact on physical and of financial capital at the village scale is a major hurdle to increase the number of CFs in Cameroon. In poor rural contexts, an increase in local welfare is a precondition for the long-term involvement of population in community forestry. The Cameroonian failure of the community forestry model so far is worrying because it has been replicated for about 15 years in Central African countries. Gabon and the Democratic Republic of Congo (DRC) have included community forestry in their new forestry regulations since the early 2000s, while the Central African Republic adopted a decree in 2015 to implement community forests, which was already provided for in its 2008 forestry law. The study of the contribution of community forestry to local livelihood improvement through the accumulation of wealth and an increase in income is particularly important in DRC where community forestry initiatives (i) have recently been backed by several legal instruments, (ii) carry the potential to cover vast surfaces of the national forests, and (iii) should be implemented with the integration of small-scale, artisanal loggers in the business model. We introduce these topics below.

\section{The rise of community forestry in the DRC, but for whose benefit?}

Several recent regulatory changes have made it possible to start community forestry in the DRC. In 2002, the DRC forestry law created the concept of "local community forest," which lacked detail but confirmed the existence of legitimate customary rights over forests (Trefon 2008). These local community forests can be requested by communities on the basis of their customary rights. Their surface area is not limited but they must be located outside classified and permanent production forests. Local community forest status confirms the possession of this space by a community but does not correspond to a title deed, which remains owned by the state.

After a decade of debates among stakeholders and practitioners (Vermeulen and Karsenty 2015), the forest law was gradually completed by three regulations with a view to opening up a pathway to formalize the vast sector of small-scale logging in the DRC (Lescuyer et al. 2014). First, Decree 14/018 dated 2 August 2014 established the concept of "local community forest concession" (LCFC) whose maximum size is 50,000 ha delineated inside a local community forest. The LCFC allows the community to formally exploit forest resources for subsistence or commercial purposes. The exploitation of resources in the LCFC must follow sustainable management rules. Then, Ministerial Order 25 dated 
Fig. 1. Pilot experiments in community forestry in the Democratic Republic of Congo.

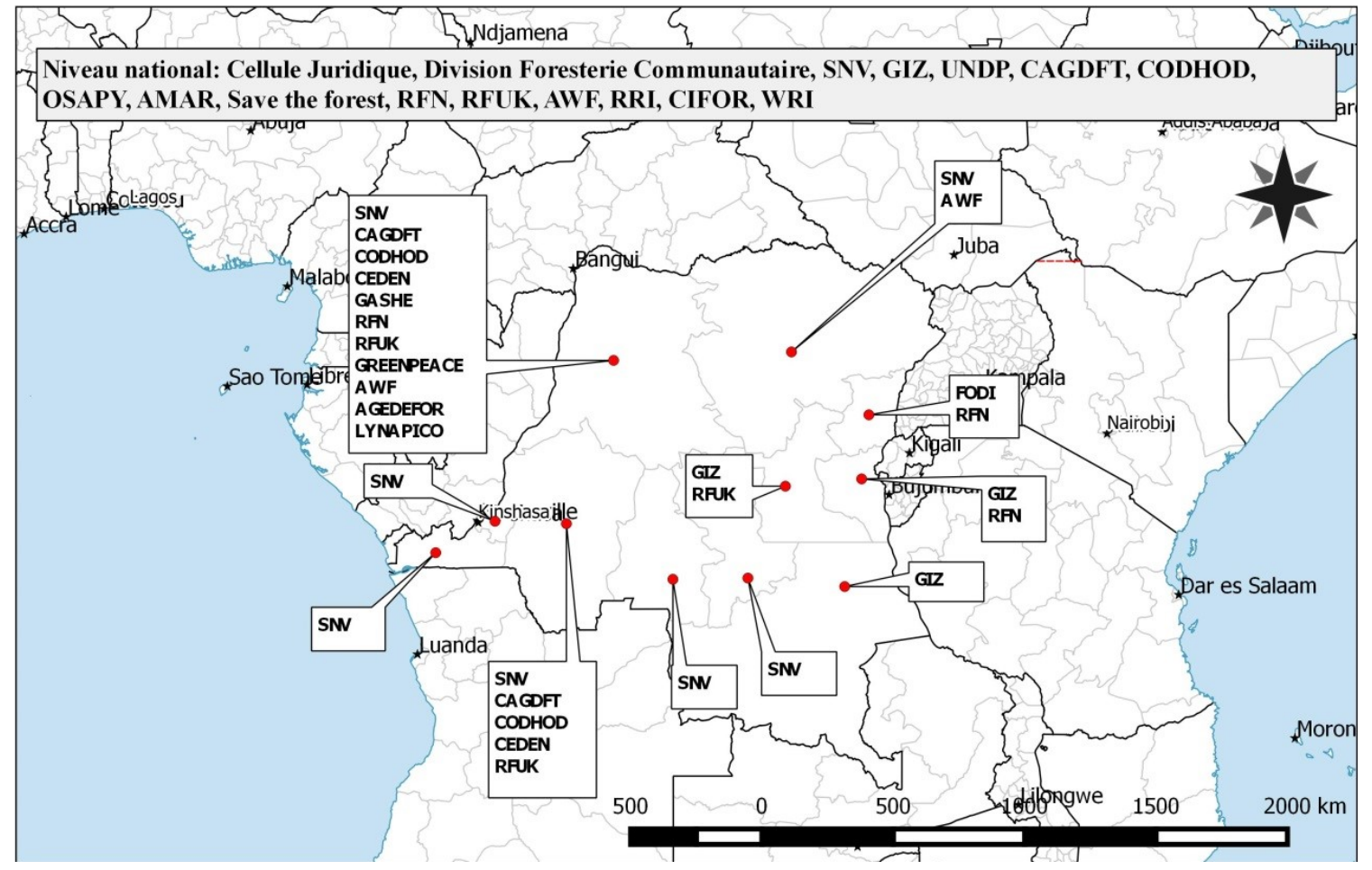

9 February 2016 provided the rules for managing and using LCFC. Last, Ministerial Order 84 dated 29 October 2016 explained how small-scale logging must be carried out inside LCFCs. A new institutional context has also been established to facilitate the enforcement of these regulations, with the creation in 2014 of a subdepartment devoted to community forestry at the Ministry of the Environment and the recent validation of a national strategy to promote community forestry in the DRC.

The concepts of local community forest and LCFC are the two current forms of CBFM in the DRC. Most CBFM initiatives have at least one of these two objectives but they are at varying levels of achievement. At the beginning of 2018, only a few LCFCs had been created and on very small surfaces. In the absence of formal recognition of a local community forest or LCFC, we will use the generic terms of CBFM or community forestry to refer to these initiatives. Since the end of the 2000s, many pilot experiments have been launched to test and contribute to the application of the CBFM approach in DRC. Figure 1 illustrates the large number of CBFM projects that were active between 2010 and 2015 (Bauer 2016).

Like in Cameroon, all these initiatives were subsidized by international funds and most of them were run by local or international NGOs. Their purpose was both to contribute to designing clear management rules for CBFM and to test them for various land uses: biodiversity protection, carbon sequestration, small-scale logging, sustainable hunting, fuelwood production. Yet their initial implementation seems to show shortcomings, and raises questions similar to those already highlighted for Cameroon (Kakelengwa et al. 2016), which we try to answer in the remaining of this article. First, does such a model have the ability to lift communities out of poverty? Second, will the redistribution of resources derived from the forest generate benefits for rural communities? These questions arise from the premise that resources from local forests should help to increase the revenues of decentralized entities and households in the communities involved, but this is still far from being demonstrated in the DRC.

The objective of this article is thus to assess the capacity of community forestry, as it is currently implemented in the DRC, to increase individual or collective incomes in rural communities. We conduct a financial analysis that applies only to real income flows and not to all the economic benefits potentially generated by a LCFC. The latter may be important, as shown by Beauchamp and Ingram (2011), but the increase in real income is a major precondition for the success of the community forestry at the local level. Our analysis also applies only to the community scale and does not take into account the potential revenues generated for nonlocal actors. Overall, our estimate focuses only on the actual financial benefits that communities can realistically expect from exploiting the resources located in the LCFC, in order to test the assumption that current CBFM experiences increase local livelihoods, notably through more revenues for the community members.

We focused on and reviewed the pilot experiments carried out in the former Eastern province, and more specifically in the provinces of Tshopo and Ituri where the largest number of pilots is found, to examine the extent to which the financial impacts of the LCFCs had been taken into account when setting up the 
Fig. 2. Location of the two sites.

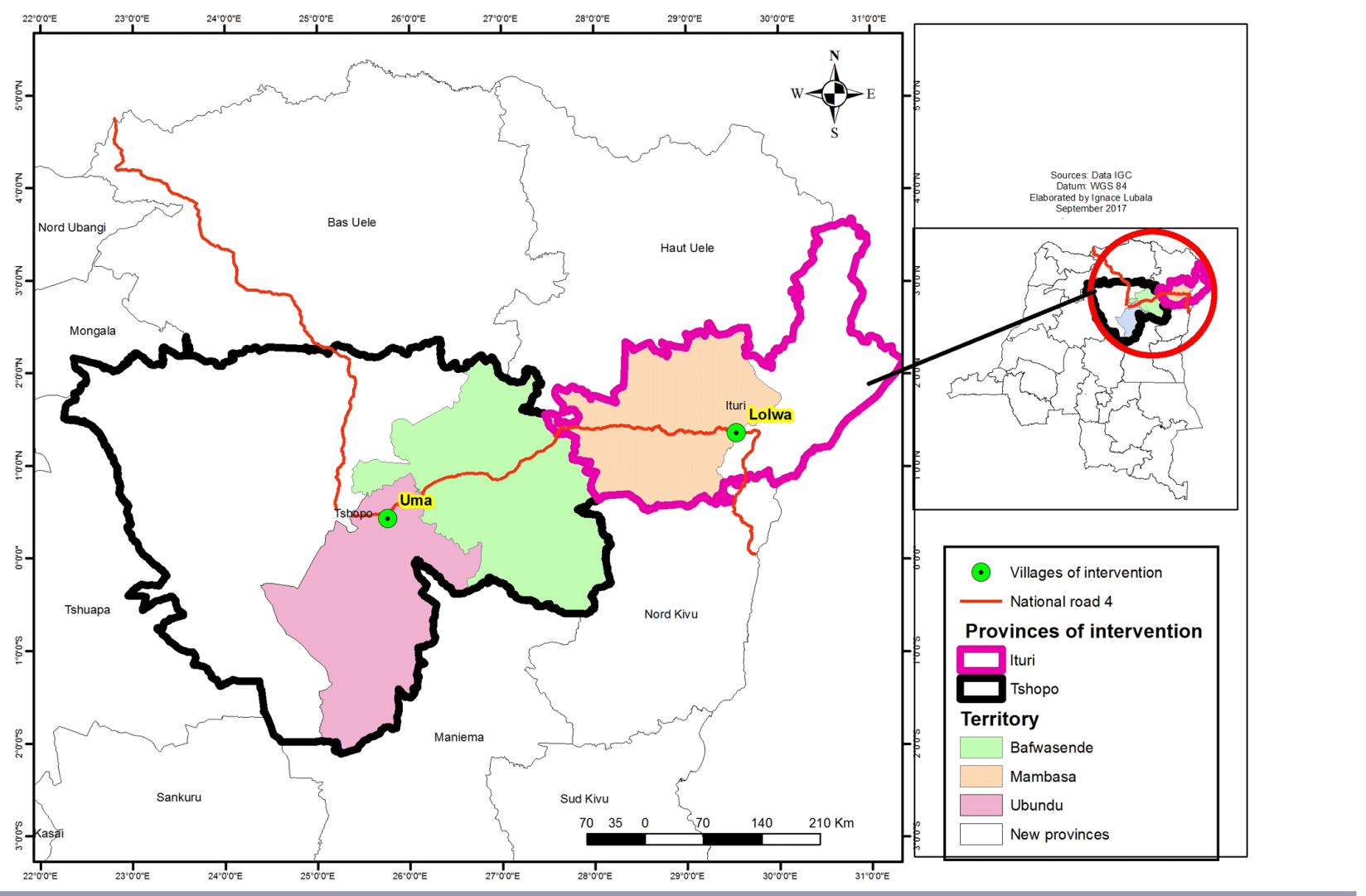

projects and we analyze the profitability of these investments for those communities. To do this, the results are organized into three sections: (1) the identification of actual sources of local revenue among the different activities envisaged in the LCFCs; (2) the estimation of the costs of creating and running a LCFC; (3) the estimation of the financial net present value of the future LCFC through the application of cost-benefit analysis. These results feed a discussion on possible measures to increase the impact of community forestry on people's incomes in order to facilitate its extension in the DRC and strengthen its contribution in the fight against poverty.

\section{METHODS}

The financial analysis of community forestry initiatives in the provinces of Tshopo and Ituri was carried out in three stages. These provinces were selected because of the high number of CBFM initiatives launched there over the latest decade (Fig. 1).

First, we identified most of the CBFM initiatives in 2016 in these two provinces by interviewing the forest administration, NGOs, the University of Kisangani, and donors known to support community forestry. We then met with the leaders of the CBFM initiative on one to three occasions, with a total of eight meetings, and collected the management documents prepared for each of these initiatives. We then selected two case studies, Lolwa and Uma, which were relatively advanced in setting up a LCFC and for which we had collected many documents that described the activities to be conducted (Fig. 2). The two experiences have been at stand still for a few years because of lack of funds to complete the procedures.

Because of a lack of official template to design the SMP, many activities to be conducted in the LCFC were little detailed and poorly quantified in the technical reports. Where information from these documents was incomplete or out of step with existing regulations, it was supplemented, adjusted, or detailed during community surveys. To that purpose, we visited the two CBFM initiatives to supplement the information collected in Kisangani. At the pilot sites, 12 focus group discussions and 50 individual interviews with key users and managers were organized. These surveys had three purposes: (1) to detail the planned activities in the future LCFC over the coming five years; (2) to quantify the financial benefits and costs expected from these activities; and (3) to depict the current practices and the institutional settings under which they can currently operate, e.g., rules of access, taxes paid, etc. All productive activities in the LCFC were carried out by the communities themselves but with the obligation to abide by the current regulations, for instance for small-scale logging or hunting permits. The main characteristics of these sites, as well as the main assumptions for the calculation of financial costs and benefits, based on data collected in the management documents, which have been adjusted/completed by socioeconomic surveys in the villages, are presented in Appendix 1.

Last, we ran a cost-benefit analysis (CBA) to quantify the financial performance of the future LCFC project through the calculation of its net present value (NPV). By definition, the 
financial benefits were related to the revenue streams accruing to the local actors (Brent 2006). Inflows consisted of sales of forest resources. They were gross financial benefits, or turn-over. Outflows were the actual costs incurred by the actors to obtain financial benefits. The total financial cost aggregated investment, operating, and transaction costs. The difference between the gross financial benefit and the financial cost was the net benefit, i.e., the profit that the actors drew from the activity.

The CBA was done for a five-year period only. This choice is justified by the high preference for the present of rural populations in the DRC, which is explained by the uncertain political and economic contexts and which is characterized in particular by a very low savings rate (Mansesa Kiakumba 2013). Hatfield (2005) used, for example, a time preference rate of $40 \%$ for subsistencelevel rural communities in the North Kivu province. In such a context, it is difficult for rural populations to make their decisions on the basis of a time horizon that exceeds a few years.

The high consumers' preference for present consumption in the DRC also influences the choice of the discount rate as it is often estimated through a combination of the marginal social rate of time preference and of the capital productivity rate. The latter is often estimated on the basis of the central bank's key rate, which varied between $15 \%$ and $23 \%$ in 2017 in the DRC. Combining these two rates, the financial discount rate should be in the range of $25 \%$ to $30 \%$. For a public or common good whose management is in the long term, it is desirable to opt for a social discount rate, whose level is much lower to better take into account the interests of future generations (Fisher and Krutilla 1975, Norgaard and Howarth 1991). However, this consideration should be played down in this study, which focuses on the financial income expected by local populations over a five-year horizon. Finally, we decided to apply a discount rate of $12 \%$, which is a compromise between the financial and social discount rates. A similar rate is also used by the African Development Bank (AfDB 2013) to assess the financial feasibility of long-term investments in road infrastructure and by the International Monetary Fund for copper and gold mines in the DRC (NRGI 2016). However, to test the sensitivity of the financial analysis results to discount rate levels, a sensitivity analysis is also conducted with a discount rate of $5 \%$ and $25 \%$. We used a parity of $1 \$$ for 1000 Congolese francs. Inflation was not considered in the calculations.

\section{RESULTS}

We bring together the main elements needed to implement the financial CBAs at the two sites, namely a list of activities generating financial benefits from the use of forest resources, an assessment of the cost of creating a LCFC, and quantification of the financial benefits and costs associated with managing the LCFC.

\section{A few forest-related and pro-poor activities in the LCFCs}

Consultation of the various management documents developed for the establishment of the LCFCs made it possible to list all the activities planned at the two sites; they are indicated by a cross in Figure 3. Out of these, we identified those that were associated with forest space (boxes marked out with horizontal lines), those for which at least some benefits and/or costs were quantified in the management documents (boxes marked out with vertical lines), and those that combined these two characteristics (boxes marked out in squares).
Fig. 3. Activities planned in the community forests. Those that were associated with forest space are marked out with horizontal lines, those for which at least some benefits and/or costs were quantified in the management documents are marked out with vertical lines, and those that combined these two characteristics are marked out in squares.

Activity mentioned in the
management documents
Animal breeding
Beekeeping
Biodiversity conservation
Carbon sequestration
Ecotourism
Fish farming
Charcoal production
Handicraft
Intensive agriculture
NTFP collection
Small-scale logging

Various activities are envisaged in each of the LCFCs, but many of them are not directly associated with forest management. For example, intensive agriculture is the main detailed and quantified activity at both sites. However, from this perspective, the SMP would become a rural development plan and not a management plan for forest-related resources.

If we focus on the forest area alone, several activities are mentioned in the management documents, such as biodiversity protection, carbon sequestration, and nontimber forest product (NTFP) harvesting, but they are not quantified. Group and individual discussions in the communities also failed to develop scenarios for the implementation of these activities, either because of a lack of data (for example for NTFPs) or because of a limited interest, or even a difficult understanding, of the communities for these activities, e.g., carbon sequestration and biodiversity conservation. In both cases, these activities do not represent a source of additional income according to these populations, either because the LCFC will not add value to the current practice of harvesting NTFPs, or because there is virtually no operational scheme of payment for environmental services for the benefit of communities in the DRC. The choice of these activities seemed to be the result of a top-down decision-making process, where the conservation-oriented agenda of the supporting NGOs (and donors) tended to impose itself on the real expectations of communities regarding the use of their natural resources.

In total, in the two case studies, there were only three activities associated with the forest area for which quantified information existed in the management documents and/or from field surveys: sustainable hunting, small-scale logging, and charcoal production. These three activities are familiar to local populations and they have been conducted extensively and informally, irrespective of the presence of the LCFC (Schure et al. 2014, 
Valimahamed et al. 2017). Communities were also aware of the longer distances and time they had to spend in conducting present-day activities as compared to 10 years ago. For instance, although in the communities hunting used to take place between $3.5 \mathrm{~km}$ and $4 \mathrm{~km}$ away 10 years ago, today such distances rise to $14.5 \mathrm{~km}$ and $17 \mathrm{~km}$, respectively. Similar increments were reported for charcoal making, logging, and agriculture. This seems to indicate that current activities, in addition to growing demographic pressure, may tend to be unsustainable in the long run. The objective of creating a LCFC is to formalize and secure these activities, while ensuring the sustainability of the harvest through compliance with the SMP. A financial feasibility assessment makes it possible to estimate the profitability of this approach for communities.

\section{Exorbitant costs of creating LCFCs}

Between 2010 and 2015, numerous steps were taken at both sites to create these LCFCs. In addition, the regulations were completed in February 2016 with the publication of Ministerial Order 25, which added several steps to the creation of a LCFC. Table 1 summarizes the total cost of creating these two LCFCs, compiling the actual expenditures at the sites and the additional expenditure required to meet current regulations.

Table 1. Cost of creating the local community forest (CF) concession at the two pilot sites.

\begin{tabular}{|c|c|c|}
\hline \multirow[t]{2}{*}{ Steps of the formal procedure } & \multicolumn{2}{|c|}{ Total cost (US\$) } \\
\hline & Uma CF & Lolwa CF \\
\hline Information and validation meetings & 4700 & 4950 \\
\hline Setting up of management committees & 9980 & 12,000 \\
\hline Delimitation and mapping & 66,470 & 16,000 \\
\hline Forest inventory & 14,825 & 11,000 \\
\hline Baseline studies & & 9500 \\
\hline Drafting of the Simple Management Plan & 4000 & 3500 \\
\hline $\begin{array}{l}\text { Drafting and filing of the logging permit } \\
\text { application }\end{array}$ & 3150 & \\
\hline $\begin{array}{l}\text { Costs for venue of provincial and national } \\
\text { authorities }\end{array}$ & 9300 & 11,200 \\
\hline Total amount of actual expenses & 112,425 & 68,150 \\
\hline \multicolumn{3}{|c|}{ Extra costs to comply with Ministerial Order 25 dated 9 February 2016} \\
\hline $\begin{array}{l}\text { Creation of Supervision and Monitoring } \\
\text { committees }\end{array}$ & \multicolumn{2}{|c|}{6120} \\
\hline Writing and adoption of new statutes & \multicolumn{2}{|c|}{5385} \\
\hline Training of the committee members & \multicolumn{2}{|c|}{9000} \\
\hline $\begin{array}{l}\text { Investments and running costs for local } \\
\text { committees }\end{array}$ & \multicolumn{2}{|c|}{12,260} \\
\hline $\begin{array}{l}\text { Costs for venue and involvement of local } \\
\text { authorities }\end{array}$ & \multicolumn{2}{|c|}{8716} \\
\hline Total cost of compliance with current regulations & 153,906 & 109,631 \\
\hline
\end{tabular}

\section{Financial CBA for the two LCFCs}

Data contained in the management documents or collected through surveys at the community level were combined to build scenarios for the use of LCFC resources over the coming five years and to quantify the respective costs and financial benefits for the two initiatives with a $12 \%$ discount rate (Tables 2 and 3).

In neither case was LCFC management cost-effective to the community from a financial point of view because the net present value was negative. The change of the discount rate does not modify the result, because the NPVs remains negative in all cases (Table 4).

Table 2. Financial cost-benefit analysis for the Lolwa local community forest concession.

\begin{tabular}{lccccc}
\hline \hline in US\$ & Year 1 & Year 2 & Year 3 & Year 4 & Year 5 \\
\hline Creation costs & 109,631 & & & & \\
Small-scale logging & & & & & \\
$\quad$ Starting costs & 64,569 & 12,630 & 12,630 & 14,915 & 12,630 \\
$\quad$ Running costs & 90,460 & 90,912 & 90,912 & 90,912 & 90,912 \\
$\quad \begin{array}{l}\text { Turn-over } \\
\text { Sustainable hunting }\end{array}$ & 121,500 & 121,500 & 121,500 & 121,500 & 121,500 \\
$\quad$ & & & & \\
$\quad$ Starting costs & 2630 & 3630 & 4630 & 3000 & 3000 \\
$\quad$ Running costs & 25,645 & 50,290 & 74,935 & 75,285 & 76,703 \\
$\quad$ Turn-over & 27,000 & 54,000 & 81,000 & 81,000 & 81,000 \\
Fuelwood collection & & & & & \\
$\quad$ Starting costs & 1255 & 1255 & 1255 & 1255 & 1255 \\
$\quad$ Running costs & 6300 & 12,600 & 18,300 & 25,200 & 31,500 \\
$\quad$ Turn-over & 12,000 & 24,000 & 36,000 & 48,000 & 60,000 \\
Net benefits & $-139,990$ & 28,183 & 35,838 & 39,933 & 46,501 \\
Net Present & $-25,251$ & & & & \\
Value & & & & & \\
\hline
\end{tabular}

Table 3. Financial cost-benefit analysis for the Uma local community forest concession.

\begin{tabular}{lccccc}
\hline \hline in US\$ & Year 1 & Year 2 & Year 3 & Year 4 & Year 5 \\
\hline Creation costs & & & & & \\
Small-scale logging & & & & & \\
$\quad$ Starting costs & 35,503 & 8298 & 10,253 & 8298 & 10,253 \\
$\quad$ Running costs & 183,844 & 172,997 & 172997 & 181,067 & 172,997 \\
$\quad$ Turn-over & 160,165 & 160,165 & 160,165 & 160,165 & 160,165 \\
Sustainable hunting & & & & & \\
$\quad$ Starting costs & 5215 & 3455 & 0 & 0 & 0 \\
$\quad$ Running costs & 36,968 & 36,968 & 36,968 & 37,643 & 38,351 \\
$\quad$ Turn-over & 54,000 & 54,000 & 54,000 & 54,000 & 54,000 \\
Net benefits & $-201,270$ & -7552 & -6052 & $-12,842$ & -7436 \\
Net Present & $-202,414$ & & & & \\
Value & & & & & \\
\hline
\end{tabular}

Table 4. Sensitivity analysis with a change of discount rate.

\begin{tabular}{lccc}
\hline \hline in US\$ & \multicolumn{3}{c}{ Discount rate } \\
\cline { 2 - 4 } & $5 \%$ & $12 \%$ & $25 \%$ \\
\hline Net Present & -7515 & $-25,251$ & $-44,012$ \\
Value Lolwa & & $-202,414$ & $-176,645$ \\
Net Present & $-220,155$ & & \\
Value Uma & & \multicolumn{3}{c}{} \\
\hline
\end{tabular}

The negative financial return of the LCFCs is explained by two reasons. On the one hand, the cost of creating the LCFC contributed very significantly to the total cost of managing a LCFC. Without this start-up cost, the Lolwa LCFC would have a positive NPV. On the other hand, the production activities planned in the LCFCs had low or even sometimes negative profit rates, which partly resulted from the substantial cost of formalizing small-scale production activities in the DRC. The cost of formalization is particularly high for chainsaw milling and this 
activity is also characterized by the payment of many salaries, which make it unprofitable in Uma and marginally profitable in Lolwa. Sustainable hunting in the two LCFCs has a positive NPV because the cost of legal hunting remains limited and because most of the time spent hunting is not paid for. But it is mainly the production of firewood that presents a high NPV in Lolwa, which is explained by low costs to access the resource, to get the equipment and to legalize this activity.

\section{DISCUSSION}

The DRC is in the start-up phase of community forestry, which partly explains the difficulties encountered in setting up LCFCs and the costs associated with this approach. However, both case studies showed that the current community forestry approach is failing financially, which will prevent real ownership of the scheme by rural populations. Two avenues are discussed to increase the financial attractiveness of community forestry in the DRC. On the one hand, community forestry should be focused on and demonstrate short-and medium-term profitable activities in rural areas. On the other hand, the complexity and formal cost of developing and managing a LCFC must be reduced to become bearable by the communities.

\section{The need to demonstrate the contribution of CBFM to households' financial capital}

In the vast majority of rural areas in tropical countries, people spend most of their time and earn most of their income from farming activities. These farming activities are a priori outside the scope of community forestry: the DRC's forest law is clear and specifically speaks of local community forests as land covered by trees or shrubs capable of providing forest products, sheltering wildlife, and having a direct or indirect effect on the soil, climate, or water regime (Vermeulen and Karsenty 2015). This therefore excludes agricultural landscapes, even if the definition of forest may include agroforestry systems or savannahs. It is unlikely that an SMP that focuses on changing agricultural practices, fish farming, or mineral exploitation could be validated by the DRC's forestry administration. Still, community forestry is therefore only one possible option to increase the financial capital of communities. Other pro-poor activities, such as the improvement and intensification of agricultural practices, can be supported by rural development actions, without the need to follow the complex process of securing forest space by setting up a LCFC.

However, in many villages, the exploitation of forest resources offers opportunities to increase the income of local populations in the short and medium term, notably through community forestry. But, as illustrated by our case studies, a common difficulty with current CBFM initiatives in the DRC is relying on an ideal vision of what LCFCs could achieve and not on the actual practices of the local population. In contrast to the Cameroonian experiments in which timber logging is the priority issue, most current CBFM initiatives in the DRC target biodiversity conservation and carbon sequestration, although these benefits remain insubstantial for local people (Eisen et al. 2014, Bauer 2016) probably because there have been very few experiences in Central Africa where these economic benefits have been converted in monetarized rewards for community (Maniatis et al. 2013). Despite the prevalent rhetoric of community empowerment and participation, community forestry is often promoted in a topdown manner in which the intervening (and often funding) agencies impose their normative values and sophisticated management tools (Pokorny et al. 2010, Maryudi et al. 2012, Hajjar et al. 2013). A bottom-up approach that takes into account the needs, wishes and current realities of communities can lead to better designed support systems than those brought in from outside (Malla et al. 2003, Thoms 2008, Hajjar et al. 2013).

The design of LCFCs on the basis of credible forest management activities is an important but not a sufficient step to maximize financial benefits for communities. It is also crucial to know whether the forest management scenario is actually beneficial for the communities and to select the most profitable options. In the two case studies, the financial return of each productive activity varies according to the natural and socioeconomic contexts, although the cost of formalization remains an overall issue for small-scale rural businesses, as observed by Anderson et al. (2015) in Cameroon, Indonesia, and Nepal.

The lack of financial viability of CFLCs in the DRC runs counter to the few estimates of the profitability of CFs, specialized in timber exploitation, summarized by Humphries et al. (2018) in Latin America and Africa, whose rates of return range from 23\% to $1133 \%$. There are several reasons for this difference. First, there is obviously a selection bias in the choice of these CFs with a focus on a few successful initiatives rather than estimating the financial results of a random sample constructed from the thousands of existing CFs. Second, several of these evaluations combine financial and economic benefits, which makes them difficult to compare and tends to inflate the profit rate for some of these studies. Finally, most of these studies do not take into account the costs of the CF creation since they are generally covered by funding from outside the communities.

However, three lessons can be drawn to make community forestry a financially viable option for communities. First of all, there is a whole consensus on the need for initial support from governments and other partners for start-up capital, subsidized access to training and technical assistance, and navigating complex bureaucratic systems (Humphries et al. 2018), without this support being transformed into substitution and dependence for communities. Second, it is crucial to analyze how local productive systems can be integrated into sustainable and lucrative value chains (Ezzine de Blas et al. 2009). Third, the implementation of an ex ante analysis of financial performance before committing to operations would allow communities and their partners to engage in activities that are not unprofitable in the medium term. To date, in DRC, no CBFM initiative has conducted an ex ante financial analysis. Similarly, the community forestry support tools package developed in 2017 by international and national NGOs, in collaboration with the DRC Ministry of Environment and Sustainable Development, does not contain any financial analysis module.

\section{The obligation to decrease the costs of procedures and institutional arrangements}

A pragmatic and profitable exploitation of forest resources is a necessary step to promote LCFC in the DRC. However, its overall impact on local livelihoods will be limited as long as communities have to bear an exorbitant cost to create and rule a LCFC. This cost is now almost entirely borne by external funders in the DRC (Bauer 2016). Without a simplification of national regulations, this dependence on external funding will prevent most rural 
populations from engaging in community forestry or will favor illegal practices to cover these costs, as the Cameroonian experience has clearly shown (Cuny 2011, Lescuyer et al. 2016).

The cost of setting up and operating a LCFC is largely attributable to the various committees set up in the community to manage this system: a committee of the elders, a community assembly, a management committee, a monitoring and control committee. The level of organization required for LCFCs is even higher than that required in other Central African countries, where organizational difficulties remain a key weakness (Karsenty, Lescuyer, Ezzine de Blas et al. 2010, unpublished manuscript). These regulatory provisions are generally justified by the will to limit the risks of abuse by traditional chiefs (Vermeulen et al. 2011). They also aim to prevent this form of decentralization from being transformed into a new way of capturing the rent derived from the exploitation of forest resources by outside private or public actors (Jacquemot 2010). However, the complexity of the local institutional set-up plays against the efficiency of the approach, requiring a significant proportion of the income generated by the LCFC to be devoted to operating the institutional system at the expense of investments for the wellbeing of the community, without avoiding elite capture either.

This multiplication of local committees in charge of the LCFC also runs the risk of being misunderstood and deemed unnecessary by the populations themselves. As shown by Milabyo Kyamusugulwa et al. (2014) in the neighboring province of North $\mathrm{Kivu}$, the local population did not press for better or more institutions on managing the projects' resources. The desire to improve the governance of common forest resources might represent a kind of supply-without-demand: the governance gap that the CBFM project seeks to fill is not necessarily experienced as such by the population, especially if its content is not consistent with people's daily lives and knowledge. Congolese regulations may have been too prescriptive in imposing these various committees and their operating procedures. A more pragmatic approach would have been to set out some broad principles of governance for CBFM, leaving each community to choose its own criteria for implementing them.

\section{CONCLUSION}

Community forestry in the DRC took many forms over the last decade before recent regulations set out more precise conditions for its implementation. These different modalities for implementing LCFCs reflect the various benefits attributed to CBFM by most of the literature on this subject. First, CFs are usually considered as an option to secure rural areas for the benefit of communities, especially in Central Africa in order to limit future possibilities for the allocation by the state of new areas of timber/crop concessions or protected areas (Nuesiri 2015, Vermeulen and Karsenty 2015). Another objective of many CBFM initiatives is also to more effectively recognize knowledge and customary rights, which is presumably needed for sustainable management of forest resources (Posey 1999). Last, community forestry is also seen as a new approach for rural development, where local capacity building for productive investment can be undertaken almost independently of whether or not there is a forest area.

However, it is important to recall the primary ambition of community forestry to contribute to enhancing the well-being of communities through the efficient and sustainable use of forest resources. In the DRC, Bauer (2016) reviewed most of these initiatives and showed that a rise in local incomes from forest uses is an objective that is rarely mentioned. This purpose cannot be forgotten, especially in rural areas where development options are scarce for local populations. It is high time to consider LCFCs as investment projects for the benefit of communities, if we want to maximize the chances of their success and ensure that the tens of millions of dollars devoted to supporting CBFM in the DRC help to alleviate poverty in rural communities.

\section{Responses to this article can be read online at: http://www.ecologyandsociety.org/issues/responses. php/10672}

\section{Acknowledgments:}

This study was supported by the REFORCO and FORETS projects (Appui à la recherche forestière au Congo and Formation, Recherche et Environnement dans la Tshopo), funded by the European Union, and by the CGIAR Research Programme on Forests, Trees and Agroforestry. The authors are grateful to Adikis (Action pour le développement intégré de Kisangani) and Osapy (Organisation d'Accompagnement et d'Appui aux Pygmées) for providing us with access to the documents prepared for the management of the two community forests. RS\&D (Resource Synergy \& Development) is also acknowledged for providing administrative and logistic support. We are also indebted to the communities of Uma and Lolwa for their availability and the time devoted to our surveys. Lastly, we thank two anonymous reviewers for their comments on the first version of this article.

\section{LITERATURE CITED}

African Development Bank (AfDB). 2013. Projet d'aménagement de la route Batshamba-Tshipaka, section Lovua-Tshipaka. Banque Africaine de Développement-OITC, Tunis, Tunisia.

Anderson, J., S. Mehta, E. Epelu, and B. Cohen. 2015. Managing leftovers: does community forestry increase secure and equitable access to valuable resources for the rural poor? Forest Policy and Economics 58:47-55. http://dx.doi.org/10.1016/j.forpol.2014.12.004

Assembe Mvondo, S., R. Eba'a Atyi, G. Lescuyer, and A. D. Wardell. 2011. Sustainable forest management based on state practice in Central Africa countries. Nature \& Faune 26(1):45-48.

Bauer, T. 2016. Cartographie des acteurs de la Foresterie Communautaire en $R D C$ - un aperçu des intervenants, de la vision et les défis dans sa mise en æuvre. GIZ - Programme Biodiversité et Forêts, Kinshasa, Democratic Republic of Congo.

Baynes, J., J. Herbohn, C. Smith, R. Fisher, and D. Bray. 2015. Key factors which influence the success of community forestry in developing countries. Global Environmental Change 35:226-238. http://dx.doi.org/10.1016/j.gloenvcha.2015.09.011

Beauchamp, E., and V. Ingram. 2011. Impacts of community forests on livelihoods in Cameroon: lessons from two case studies. International Forestry Review 13(4):389-403. http://dx.doi. org/10.1505/146554811798811371 
Brent, R. J. 2006. Applied cost-benefit analysis. Edward Elgar, Cheltenham, UK.

Cernea, M. 1986. Putting people first: sociological variables in rural development. World Bank Technical Paper 80, Washington, D.C., USA.

Chambers, R., and G. R. Conway. 1992. Sustainable rural livelihoods: practical concepts for the 21 st century. IDS Discussion Paper 296. Institute for Development Studies, Brighton, UK.

Cuny, P. 2011. Etat des lieux de la foresterie communautaire et communale au Cameroun. Tropenbos International, Wageningen, the Netherlands.

Cuny, P., P. Abe'ele, G. M. Nguenang, N. A. Eboule Singa, A. Eyene Essomba, and R. Djeukam. 2004. Etat des lieux de la foresterie communautaire au Cameroun. MINEF and DFID, Yaounde, Cameroon.

De Jong, W., B. Pokorny, P. Katila, G. Galloway, and P. Pacheco. 2018. Community forestry and the sustainable development goals: a two way street. Forests 9(6):331. http://dx.doi. org/10.3390/f9060331

Edmunds, D. S., and E. K. Wollenberg. 2003. Local forest management: the impact of devolution policies. Earthscan, London, UK. http://dx.doi.org/10.4324/9781849771856

Eisen, J., S. Counsell, and F. Thornberry. 2014. Rethinking community based forest management in the Congo Basin. Under the Canopy series, Rainforest Foundation, London, UK.

Ekoko, F. 2000. Balancing politics, economics and conservation: the case of the Cameroon forestry law reform. Development and Change 31(1):131-154. http://dx.doi.org/10.1111/1467-7660.00149

Etoungou, P. 2003. Decentralization viewed from inside: the implementation of community forests in east Cameroon. Environmental Governance in Africa Working Paper no. 12. World Resources Institute, Washington, D.C., USA.

Ezzine de Blas, D., M. Ruiz Pérez, J. A. Sayer, G. Lescuyer, R. Nasi, and A. Karsenty. 2009. External influences on and conditions for community logging management in Cameroon. World Development 37(2):445-456. http://dx.doi.org/10.1016/j. worlddev.2008.03.011

Fisher, A. C., and J. V. Krutilla. 1975. Resource conservation, environmental preservation, and the rate of discount. Quarterly Journal of Economics 89(3):358-370. http://dx.doi.org/10.2307/1885257

Gibson, C. G., M. A. McKean, and E. Ostrom, editors. 2000. People and forests: communities, institutions, and governance. MIT Press, Cambridge, Massachusetts, USA. http://dx.doi.org/10.7551/ mitpress/5286.001.0001

Hajjar, R., R. A. Kozak, H. El-Lakany, and J. L. Innes. 2013. Community forests for forest communities: integrating community-defined goals and practices in the design of forestry initiatives. Land Use Policy 34:158-167. http://dx.doi.org/10.1016/ j.landusepol.2013.03.002

Hajjar, R., J. A. Oldekop, P. Cronkleton, E. Etue, P. Newton, A. J. M. Russel, J. Sinarra Tjajadi, W. Zhou, and A. Agrawal. 2016. The data not collected on community forestry. Conservation Biology 30(6):1357-1362. http://dx.doi.org/10.1111/cobi.12732
Hanna, S. S., C. Folke, and K. G. Mäler. 1996. Rights to nature. Ecological economics, cultural, and political principles of institutions for the environment. Island Press, Washington, D.C., USA.

Hatfield, R. 2005. Economic value of the Bwindi and Virunga gorilla mountain forests. African Wildlife Foundation, Nairobi, Kenya.

Humphries, S., T. Holmes, D. F. Carvalho de Andrade, D. McGrath, and J. Batista Dantas. 2018. Searching for win-win forest outcomes: learning-by-doing, financial viability, and income growth for a community-based forest management cooperative in the Brazilian Amazon. World Development, in press. http://dx.doi.org/10.1016/j.worlddev.2018.06.005

Humphries, S., T. P. Holmes, K. Kainer, C. G. G. Koury, E. Cruz, and R. de Miranda Rocha. 2012. Are community-based forest enterprises in the tropics financially viable? Case studies from the Brazilian Amazon. Ecological Economics 77:62-73. http://dx.doi. org/10.1016/i.ecolecon.2011.10.018

Jacquemot, P. 2010. La résistance à la "bonne gouvernance" dans un état africain. Réflexions autour du cas congolais (RDC). Revue Tiers Monde 204:129-146. http://dx.doi.org/10.3917/rtm.204.0129

Julve Larrubia, C., P. P. Tabi Eckebil, N. Nzoyem Saha, J. C. Tchantchouang, B. Kerkhofs, A. Beauquin, J. P. Mbarga Mbarga, C. Vermeulen, P. O. Cerutti, and G. Lescuyer. 2013. Forêts communautaires camerounaises et plan d'action "forest law enforcement, governance and trade" (FLEGT) : quel prix pour la legalité? Bois et Forêt des Tropiques 317:71-80. http://dx.doi. org/10.19182/bft2013.317.a20526

Kakelengwa, B., C. Benneker, P. Matata, and I. Muganguzi. 2016. Dynamique de gestion locale des forêts: Base de la foresterie communautaire en Province Orientale, République Démocratique $d u$ Congo. Tropenbos International RD Congo, Kisangani, Democratic Republic of Congo.

Kellert, S. R., J. N. Mehta, S. A. Ebbin, and L. L. Lichtenfeld. 2000. Community natural resource management: promise, rhetoric, and reality. Society and Natural Resources 13(8):705-715. http://dx.doi.org/10.1080/089419200750035575

Lescuyer, G., P. O. Cerutti, and R. Tsanga. 2016. Contributions of community and individual small-scale logging to sustainable timber management in Cameroon. International Forestry Review 18(S1):40-51. http://dx.doi.org/10.1505/146554816819683744

Lescuyer, G., P. O. Cerutti, P. Tshimpanga, F. Biloko, B. Adebu Abdala, R. Tsanga, R. Yembe Yembe, and E. Essiane Mendoula. 2014. The domestic market for small-scale chainsaw milling in the Democratic Republic of Congo: present situation, opportunities and challenges. Occasional Paper 112. CIFOR, Bogor, Indonesia.

Malla, Y. B., H. R. Neupane, and P. J. Branney. 2003. Why aren't poor people benefiting more from community forestry? Journal of Forest and Livelihood 3(1):78-93.

Maniatis, D., J. Gaugris, D. Mollicone, J. Scriven, A. Corblin, C. Ndikumagenge, A. Aquino, P. Crete, and M.-J. Sanz-Sanchez. 2013. Financing and current capacity for REDD+ readiness and monitoring, measurement, reporting and verification in the Congo Basin. Philosophical Transactions of the Royal Society 368 (1626):20130413. http://dx.doi.org/10.1098/rstb.2013.0413 
Mansesa Kiakumba, G. T. 2013. Epargne et bien-être des ménages en RDC. Une analyse macro et microéconomique. Thesis. Université de Kinshasa, Kinshasa, Democratic Republic of Congo.

Maryudi, A., R. R. Devkota, C. Schusser, C. Yufanyi, M. Salla, H. Aurenhammer, R. Rotchanaphatharawit, and M. Krott. 2012. Back to basics: considerations in evaluating the outcomes of community forestry. Forest Policy and Economics 14:1-5. http:// dx.doi.org/10.1016/j.forpol.2011.07.017

Milabyo Kyamusugulwa, P., D. Hilhorst, and G. Van Der Haar. 2014. Capacity builders for governance: community-driven reconstruction in the eastern Democratic Republic of Congo. Development in Practice 24(7):812-826. http://dx.doi. org/10.1080/09614524.2014.944484

Natural Resource Governance Institute (NRGI). 2016. Guide d'utilisation des modèles économiques et financiers de NRGI-Mine d'or et mine de cuivre. NRGI report, New York, New York, USA.

Nguinguiri, J. C. 1999. Les approches participatives dans la gestion des écosystèmes forestiers d'Afrique centrale. Occasional Paper 23. CIFOR, Bogor, Indonesia.

Norgaard, R. B., and R. B. Howarth. 1991. Sustainability and discounting the future. Pages 88-101 in R. Costanza, editor. Ecological economics: the science and management of sustainability. Columbia University Press, New York, New York, USA.

Nuesiri, E. O. 2015. Monetary and non-monetary benefits from the Bimbia-Bonadikombo community forest, Cameroon: policy implications relevant for carbon emissions reduction programmes. Community Development Journal 50(4):661-676. http://dx.doi.org/10.1093/cdj/bsu061

Oyono, P. R. 2005. Profiling local-level outcomes of environmental decentralizations: the case of Cameroon's forests in the Congo Basin. Journal of Environment and Development 14 (2):1-21.

Oyono, P. R., M. B. Biyong, and S. Komba Samba. 2012. Beyond the decade of policy and community euphoria: the state of livelihoods under new local rights to forest in rural Cameroon. Conservation and Society 10(2):173-181. http://dx.doi. org/10.4103/0972-4923.97489

Oyono, P. R., J. C. Ribot, and A. M. Larson. 2006. Green and black gold in rural Cameroon: natural resources for local governance, justice and sustainability. Environmental Governance in Africa Working Paper Series no. 22. World Resources Institute, Washington, D.C., USA.

Pagdee, A., Y. S. Kim, and P. J. Daugherty. 2006. What makes community forest management successful: a meta-study from community forests throughout the world. Society and Natural Resources 19:33-52. http://dx.doi.org/10.1080/08941920500323260

Pokorny, B., C. Sabogal, W. de Jong, P. Pacheco, N. Porro, B. Louman, and D. Stoian. 2010. Challenges of community forestry in tropical America. Bois et Forêts des Tropiques 303:54-66.

Posey, D. A., editor. 1999. Cultural and spiritual values of biodiversity. United Nations Environment Programme, Nairobi, Kenya. http://dx.doi.org/10.3362/9781780445434
Ribot, J. C., J. F. Lund, and T. Treue. 2010. Democratic decentralization in sub-Saharan Africa: its contribution to forest management, livelihoods, and enfranchisement. Environmental Conservation 37(1):35-44. http://dx.doi.org/10.1017/S0376892910000329

Schure, J., P. Levang, and F. K. Wiersum. 2014. Producing woodfuel for urban centers in the Democratic Republic of Congo: a path out of poverty for rural households? World Development 64(S1):S80-S90. http://dx.doi.org/10.1016/j.worlddev.2014.03.013

Scoones, I. 1998. Sustainable rural livelihoods: a framework for analysis. IDS Working Paper 72. Institute for Development Studies, Brighton, UK.

Thoms, C. A. 2008. Community control of resources and the challenge of improving local livelihoods: a critical examination of community forestry in Nepal. Geoforum 39:1452-1465. http:// dx.doi.org/10.1016/j.geoforum.2008.01.006

Tole, L. 2010. Reforms from the ground up: a review of community-based forest management in tropical developing countries. Environmental Management 45:1312-1331. http://dx. doi.org/10.1007/s00267-010-9489-Z

Topa, G., A. Karsenty, C. Megevand, and L. Debroux. 2009. Forêts tropicales humides du Cameroun: une décennie de réformes. Banque Mondiale, Washington, D.C., USA. http://dx.doi. org/10.1596/978-0-8213-7879-3

Trefon, T. 2008. La réforme du secteur forestier en République démocratique du Congo: défis sociaux et faiblesses institutionnelles. Afrique contemporaine 227:81-93. http://dx.doi. org/10.3917/afco.227.0081

Valimahamed, A., G. Lescuyer, and R. Nasi. 2017. Contributions de la chasse villageoise aux économies locales et nationales au Congo et en République démocratique du Congo. Pages 15-36 in N. van Vliet, J. C. Nguinguiri, D. Cornélis, and S. Le Bel, editors. Communautés locales et utilisation durable de la faune sauvage en Afrique Centrale. FAO-CIFOR-CIRAD, Bogor, Indonesia.

Vermeulen, C., E. Dubiez, P. Proces, S. Diowo Mukumary, T. Yamba Yamba, S. Mutambwe, R. Peltier, J. N. Marien, and J. L. Doucet. 2011. Enjeux fonciers, exploitation des ressources naturelles et Forêts des Communautés Locales en périphérie de Kinshasa, RDC. Biotechnologie, Agronomie, Société et Environnement 15(4):1-10.

Vermeulen, C., and A. Karsenty. 2015. Les concessions forestières des communautés locales: une avancée potentielle pour la foresterie sociale en RDC. Cahiers Africains - Afrika Studies 86:97-112.

Vermeulen, C., M. Vandenhaute, M. Dethier, H. Eckodek, G. M. Nguenang, and W. Delvingt. 2006. De Kompia à Djolempoum: sur les sentiers tortueux de l'aménagement et de l'exploitation des forêts communautaires au Cameroun. VertigO 7(1):7. 
Appendix 1. Main characteristics and calculation assumptions of the sampled LCFCs

Table A1.1: Variables and assumptions used for the cost-benefit analysis of the LCFC of Lolwa

Surface area (ha)

Start of the process

Accomplished steps

Consulted

documents

Category

Starting costs

Running costs

298903

2013

SMP completed but not aligned with present regulations

SMP, multiple resources inventory report, training reports

Small-scale logging

\section{Variables Assumptions}

Social requirements ("Cahiers des charges")

Official agreement for small-scale logging

Purchase of chainsaws

Training of small-scale loggers on improved logging techniques

Trees inventory in the annual logging area

Purchase of the logging permits

Logging and chainsaw milling costs
One "cahier des charges" is required for each of the 11 harvesting permits. Each logging permist covers an area of $20 \mathrm{ha} / \mathrm{yr}$

One agreement is required for each chainsaw miller

One chainsaw for each logging permit; unit price in Kisangani

A one-week workshop for the 11 small-scale loggers by a national expert based in Kisangani

One inventory of valuable trees in each of the 11 smallscale logging areas

11 permits every year

for $450 \mathrm{~m} 3$ of timber per year
Source

SMP, our surveys, Lescuyer et al. 2014

official fees

our surveys

our surveys

SMP, our surveys

official fees

SMP, Lescuyer et al. 2014 
Turn over

area, timb species and volume

Price of sawn wood

\section{Sustainable hunting}

Category

Variables

Wildlife inventory

Purchase of rifles

Starting costs

\section{Running costs} food

Training

\section{Harvesting permits}

Turn over

Category market Kisangani bought.
215 ha are logged; $450 \mathrm{~m} 3$ of timber are logged from 3 timber species (linzo, liboyo, mpunga); $150 \mathrm{~m} 3$ of sawn wood are made

Prices on the Kisangani market: $260 \mathrm{USD} / \mathrm{m} 3$ for linzo and liboyo; 290 USD/m3 for mpunga

wildlife inventory already done in the SMP

the wildlife inventory is already done for the SMP; 30 hunters can do subsistence and (marginally) commercial hunting in the area, with 10 new hunters involved every year until Year 3; unit price of rifle on the Kisangani

10 hunters are trained in the first three years during a one-week workshop by a national expert based in

Each producer does 2 hunts (of a few days each) per month, over a 9 month period. Most hunting activities are unpaid as done by the household, but hiring bushmeat carriers is often needed (25USD/month).

Equipment (cartridge, knife, lamp,...) and food must be

10 permits for Year 1, 20 for Year 2, 30 permits for the following years

Each hunting trip provides an average income of 150USD to the hunter our surveys

Source

SMP

SMP, Lescuyer et al. 2014

SMP, our surveys

our surveys

our surveys, Valimahamed et al. 2017

official fees

our surveys, Valimahamed et al. 2017

Source 
Resource inventory

\section{Training}

Starting costs

Running costs

Oven

Wages for logging and cutting up

Maintenance of the oven

Equipment (bags)

Turn over
Tree inventory for charcoal production is already done in the LCFC for the SMP: resource is abundant for the 5

most valuable species

5 fuelwood producers are trained in the first five years

during a one-week workshop by a national expert based in Kisangani

Ovens are already available and will be maintained every year

Most activities of charcoal production are unpaid as done by the household, but some technical activities require to hire chainsaw millers. The average costs is 40

$\mathrm{USD} /$ month/producer for an average monthly production of 25 bags

maintenance and operating costs of 50USD a month for a monthly production of 25 bags

Unit price on the Kisangani market

Each producer trades 300 bags of charcoal every year for

Harvested volume and price local and regional consumption. Charcoal bags are sold at the village gate price our surveys

our surveys

our surveys, Schure et al.

our surveys

our surveys

our surveys, Schure et al. 
Table A1.2: Variables and assumptions used for the cost-benefit analysis of the LCFC of Uma

Surface area (ha)

Start of the process

Accomplished steps

Consulted documents

\section{5}

SMP to be submitted, but not aligned with present regulations

SMP, socio-economic report, forest inventory report, gender report, expenses assessment report, annual activity reports
Category

Running costs

\section{Variables}

Small-scale logging

Social requirements ("Cahiers des charges")

Building of a warehouse

Official agreement for small-scale logging

Purchase of chainsaws and

bicylces

Training of small-scale loggers on improved logging techniques

Road maintenance

Trees inventory in the annual logging area

Purchase of two pirogues

Purchase of the logging permits

Logging and chainsaw milling costs $50 \mathrm{ha} / \mathrm{yr}$

\section{Assumptions}

Already done for the SMP for a logging area of 20971 ha with a felling cycle of 25 years

One "cahier des charges" is required for each of the 15

harvesting permits. Each logging permist covers an area of

5,000 USD by a Kisangani-based entreprise

One agreement is required for each chainsaw miller

One chainsaw and one bicycle for each logging permit; unit price in Kisangani

A one-week workshop for the 15 small-scale loggers by a national expert based in Kisangani in Years 1-3-5

Wage to local labor for $9 \mathrm{~km}$ every year

839 ha are inventoried and logged every year

Local production and price

15 permits every year

for $2431 \mathrm{~m} 3$ of timber per year
Source

SMP, Forest inventory report

our surveys, expenses assessment report

socio-economic report official fees

our surveys

expenses assessment report

Socio-economic report

Forest inventory report, socioeconomic report

Socio-economic report official fees

SMP, Lescuyer et al. 2014 
Turn over and volume

Price of sawn wood

Category

Variables

Wildlife inventory

Starting costs

Running costs

Turn over
Wages, equipement and food

Harvesting permits

Purchase of rifles

Training

Harvested volume and price
839 ha are logged; $2431 \mathrm{~m} 3$ of timber are logged from 6 species; $729 \mathrm{~m} 3$ of sawn wood are made

Prices on the Kisangani market for acajou, afrormosia, iroko, kosipo, sapelli, sipo

\section{Sustainable hunting}

\section{Assumptions}

Already done for the SMP for a hunting area of 26214 ha with a 25 year harvesting cycle

15 hunters can do subsistence and (marginally) commercial hunting in the area; unit price of rifle on the Kisangani market

15 hunters are trained in the first two years during a oneweek workshop by a national expert based in Kisangani Each producer does 2 hunts (of a few days each) per month, over a 9 month period. Most hunting activities are unpaid as done by the household, but hiring bushmeat carriers is often needed (25USD/month). Equipment (cartridge, knife, lamp,...) and food must be bought.

15 permits

Each hunting trip provides an average income of 200USD to the hunter
SMP, socio-economic report, forest inventory report,

Lescuyer et al. 2014

our surveys

\section{Source}

SMP, forest resources inventory

expenses assessment report, activities report, our surveys

activities report, our surveys

our surveys, expenses assessment report,

Valimahamed et al. 2017

official fees

our surveys, socio-economic report 